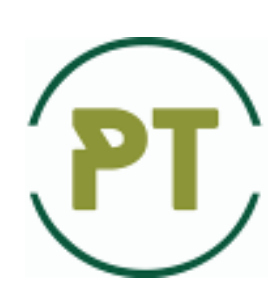

\title{
Problems of Tribology
}

Website: http://tribology.khnu.km.ua/index.php/ProbTrib

E-mail: tribosenator@gmail.com

DOI: https://doi.org/10.31891/2079-1372-2021-100-2-50-57

\section{Technological factors influence on the antifriction coatings quality}

\author{
I.V. Shepelenko \\ Central Ukrainian National Technical University, Ukraine \\ E-mail: kntucpfzk@gmail.com
}

\begin{abstract}
The conditions for the antifriction coatings formation during finishing antifriction non-abrasive treatment (FANT) are analyzed. The requirements for this kind of coatings and the main criteria for assessing their quality are noted. A relationship has been established between the quality of the coating obtained with FANT and the technological factors that determine the conditions for contacting the tool with the treated surface. It is proved that the shape and size of microroughnesses of the treated surface determine the efficiency of the microcutting process and filling the microcavities with the rubbed material.

Technological factors influence on the coating quality was investigated during FANT by implementing a multifactor experiment, as a result of which a connection was established between the technological parameters of the process (total friction path, load on the tool), as well as the length of the supporting surface with indicators characterizing the coating quality.

Statistical models were obtained for mass transfer of antifriction material, area (continuity) of the coating and surface roughness at natural values of the factors, which made it possible to establish the studied factors influence on the optimization parameters.

The analysis of the experimental scattering graphs made it possible to clarify the nature of the factors changes and analyze their mutual influence on the optimization criteria. Taking into account the inversely proportional relationship of the optimization criteria, the achievement of their maximum values at the same time is impossible, therefore, the values are taken according to the final result of the FANT process.

The range of the studied factors values is established, the regularities of their change are substantiated from the point of view of the selected optimization criteria. Determination the rational values of the FANT process technological parameters will improve the antifriction coatings quality obtained by a friction-mechanical method.
\end{abstract}

Key words: finishing antifriction non-abrasive treatment (FANT), antifriction coating, optimization, continuity coating, mass transfer, roughness.

\section{Introduction}

A generally recognized direction in the field of the working surfaces of machine parts quality improving is the development and widespread use of antifriction coatings [1]. From all the variety of methods for obtaining antifriction coatings, coatings with optimal values of hardness and elasticity modulus with increased antifriction properties, providing the favorable internal stresses creation, as well as maximum adhesion characteristics of the coating with the base material, seem to be preferable [2].

Such kind of coatings can be obtained by frictional rubbing of plastic metals by finishing antifriction nonabrasive treatment (FANT) [3]. Rubbing the friction surface with a tool made of copper and its alloys in the presence of a process fluid makes it possible to create coatings with a thickness of $2-5$ microns on the friction surface, as well as to harden the surface of the base material to a depth of 70-80 microns due to high pressure at the point of linear contact. FANT, characterized by environmental friendliness, makes it possible to reduce the running-in time of parts, eliminate scuffing of friction surfaces, increase the bearing capacity of parts and joints, protect the friction surface from hydrogen wear, reduce the friction temperature and extend the operating period of the friction unit when the lubricant supply is turned off, reduce the coefficient of friction, etc. [4]. 
The antifriction coating formation during FANT largely depends on technological factors that determine the conditions for contacting the tool with the treated surface, and the shape and size of microroughnesses determine the quality of the resulting coating, its continuity [5]. The study of the contacting surfaces features, as well as the main parameters of the FANT process, their regularities will improve the antifriction coating quality, and hence the operational properties of the part. In this regard, studies of the main parameters influence of the FANT process on the formation of an antifriction coating, depending on the conditions of contact interaction of a copper-containing tool with a treated surface, seem to be very relevant.

The widespread use of FANT is also hindered by the lack of extensive information on the relationship between the technological factors of the process and the geometric parameters of the surface layer, and above all, with the roughness, which, according to a number of researchers [6,7], is one of the main criteria for the resulting coating quality. Thus, it becomes necessary to conduct special studies of the technological factors influence that determine FANT on the antifriction coating quality.

\section{Literature review}

A number of requirements are imposed on antifriction coatings, regardless of the methods of their formation, the main of which should be attributed [8]:

- density and continuity;

- high adhesion to the metal surface;

- uniformity of the coating in thickness and a sufficiently high cleanliness of its surface;

- the ability, together with the base metal, to withstand operational loads;

- durability.

These requirements determine the coatings quality obtained with FANT.

In a number of studies devoted to the formation of the FANT antifriction coating, the authors of studies [9] consider surface roughness to be one of the main criteria for assessing the quality of the applied skin. Earlier it was proved that the surface roughness parameters are one of the main factors that determine the intensity of the friction pairs wear [10], in a certain way affect the indicators of its physical state (cold-hardening, internal stresses, microcracks, structure) [11] have a significant effect of roughness on corrosion resistance [12] and on the reliability of parts fixed joints [13]. Due to the fact that the authors of [14] obtained and substantiated the initial microrelief of the surface to create favorable conditions for microcutting the antifriction material with microprotrusions of the initial surface and to improve the coating formation quality by the friction-mechanical method, it becomes necessary to conduct special studies of the FANT influence with the established parameters on the roughness of surface layer.

According to [7], such parameters as the coating thickness, as well as its adhesion to the base material, play a key role in the coatings quality. An important factor is the stress-deformed state of the surface layer and the initial microgeometry.

In [15], as an assessment of the coatings quality obtained with FANT, the following were used: the coating thickness, the degree of its porosity, the roughness parameter, and wear resistance. It should be noted the inconsistency of information available in the available literature. Thus, the authors of [16] obtained a coating thickness by the friction method in the range of $0.3-0.5$ microns, and in [17], a coating thickness of about 30 40 microns was obtained. Such a large difference in the results indicates the need for additional studies to determine the coating thickness.

The authors of [18] made an attempt to optimize the process of applying antifriction coatings. For this purpose, the quality of processing was assessed using points, and the parameters were taken: the color of the coating; reducing the length of the rubbing rod - the intensity of rubbing; uneven coating - gaps in the applied layer; smoothing the coating layer. This approach to assessing the coating quality and the effectiveness of the FANT technology, according to [15], is inaccurate, since the color, thickness, porosity and other indicators are indirect characteristics of the coating quality, they can be used at the stage of testing the coating technology. The main indicator of the coating quality is its wear resistance (ability to resist wear).

The results of wear tests of antifriction coatings formed by the friction-mechanical method from various materials (brass, bronze, copper) are presented in [19]. However, the difference in coating applying modes, the lack of information about measuring instruments raise doubts about the information reliability and the experimental technique correctness.

The given data of literary sources do not allow assessing the effectiveness of the FANT technology. In this regard, it becomes necessary to conduct research to determine the influence of the technological parameters of the FANT process on the coating quality obtained by the friction-mechanical method.

\section{Purpose}

The aim of the work is to establish the basic laws of the technological factors influence of the FANT process on the resulting coating quality. 


\section{Research Methodology}

To achieve this goal, the greatest difficulty is presented by studies to determine the factors influence on the optimization parameters. Such studies should include the influence on the indicators characterizing the applied coating quality (area (continuity), roughness and mass transfer of antifriction material from the tool) of the main processing modes: the friction path $L$ and the load on the tool $P$, as well as the supporting surface length of the treated sample $\Delta l$. In order to reduce the number of experiments for these studies, the planning of experiments was carried out.

The study of the surface, processed by the FANT friction-mechanical method, was carried out on special samples of gray cast iron $\mathrm{SCH} 20$ made in the form of disks, on which a preliminary applied microrelief with different $\Delta l$ (Fig. 1).

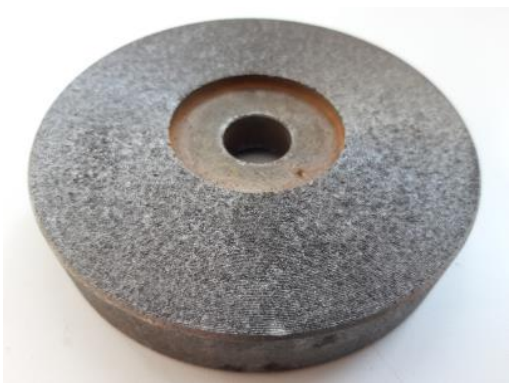

$\mathbf{a}$

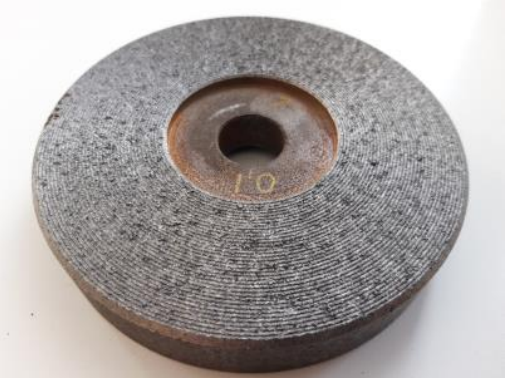

b

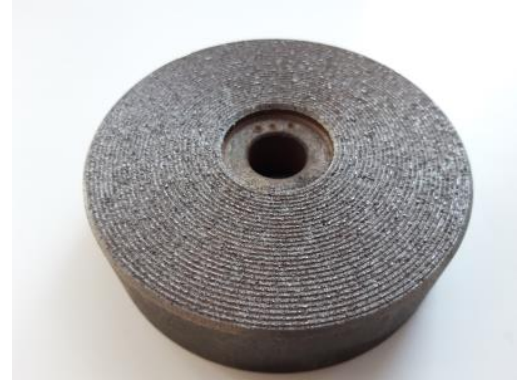

c

Fig. 1. Samples of cast iron SCH20,

processed by the FANT friction-mechanical method with different $\Delta l$ :

$$
\begin{gathered}
\text { a }-\Delta l=0,2 \mathrm{~mm} ; \\
\mathrm{b}-\Delta l=0,4 \mathrm{~mm} ; \\
\text { c }-\Delta l=0,6 \mathrm{~mm}
\end{gathered}
$$

The friction path was changed within $2 \ldots 30 \mathrm{~mm}$ by varying the length of the brass tool (Fig. 2) and the number of its passes.

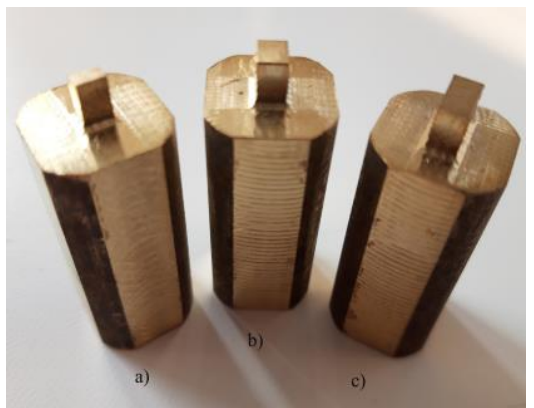

Fig. 2. Tools for frictional mechanical processing with different lengths $l$ :

$$
\begin{gathered}
\mathrm{a}-l=2 \mathrm{~mm} ; \\
\mathrm{b}-l=4 \mathrm{~mm} ; \\
\mathrm{c}-l=6 \mathrm{~mm}
\end{gathered}
$$

Thus, the total friction path was calculated taking into account the tool size using the formula:

$$
L=l \cdot N
$$

where $-l$ is the length of the tool, mm;

$N-$ is the number of cycles (passes) of the tool.

The value of mass transfer was determined by weighing the instrument before and after FANT on a TBE-0,21-0,001 laboratory scales (Fig. 3, a) according to the formula:

$$
\Delta m=m_{1}-m_{2},
$$

where $-m_{1}$ is the tool mass before FANT, $\mathrm{g}$;

$m_{2}-$ tool mass after FANT, g. 


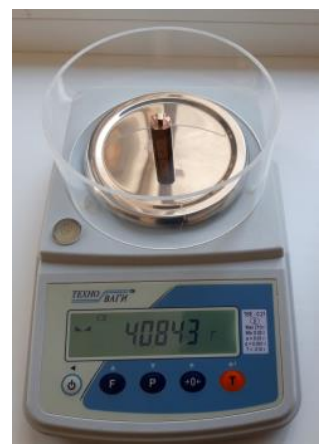

a

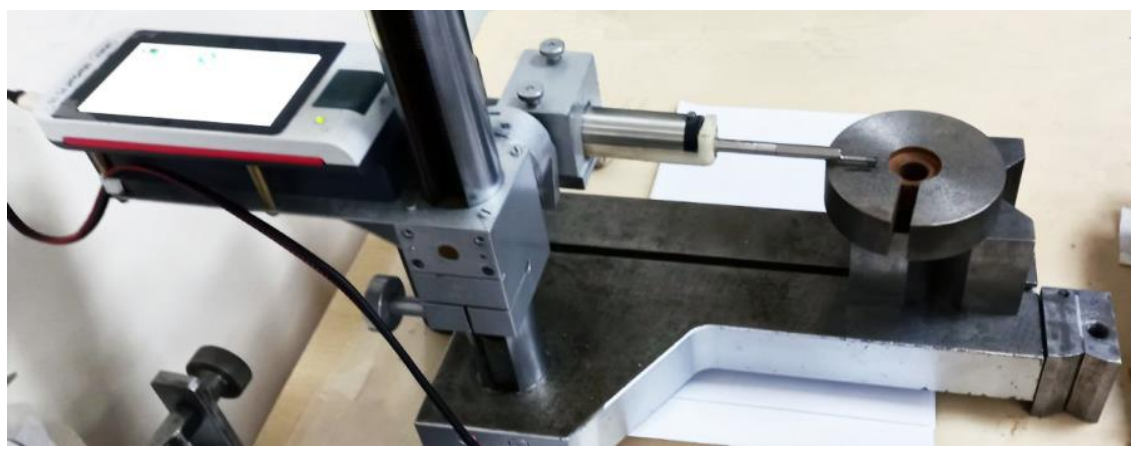

b

Fig. 3. Weighing a brass tool after FANT (a)

and measuring the roughness of the machined surface (b)

Under the selected conditions and processing modes, antifriction coatings were applied on the surface of the studied samples (Fig. 4) by a friction-mechanical method using a setup developed by the authors [20].

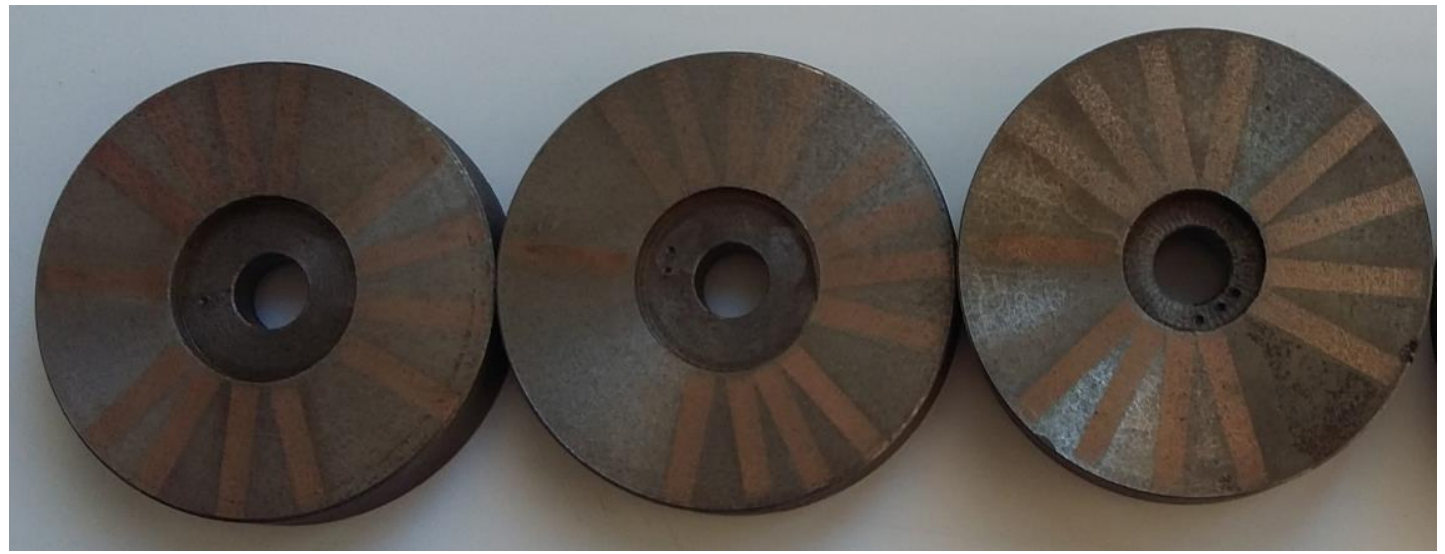

Fig. 4. Studied samples with an antifriction coating applied by a friction-mechanical method

Coverage area (continuity) based on the results of metallographic analysis of the surface using digital image processing methods on a PC. For this purpose, a program was written in C ++ using the Qt framework and the OpenCV image processing libraries.

Surface roughness before and after FANT was assessed using a Mahr XR20 profilograph (Fig. 3, b), a PC-based device that allows to determine more than 75 parameters of roughness, waviness, P-profile and Motifparameters in accordance with international standards.

The aim of the experiments series was to implement a matrix of the central compositional plan $2^{3}+$ star points, resulting in the factors influence ( $L \times n$ (total friction path), $P_{\Sigma}$ (force per 1 microroughness of $1 \mathrm{~mm}$ of its width), $\Delta l$ (length contact)) on the indicators characterizing the coating quality obtained with FANT. 


\section{Results}

The STATISTICA 12.0 application software package was used to process the experimental data, as a result of which statistical mathematical models were constructed for the coating mass $m\left(Y_{1}\right)$, the coverage area $S_{n} / S\left(Y_{2}\right)$ and the surface roughness $R_{a} / R_{a \text { init }}\left(Y_{3}\right)$ at natural values of factors:

$$
\begin{gathered}
Y_{1}(m)=0,005519+0,000735 \cdot x_{1}-0,000462 \cdot x_{2}-0,001442 \cdot x_{3}- \\
-0,001895 \cdot x_{1}^{2}-0,001603 \cdot x_{2}^{2}-0,001799 \cdot x_{3}^{2}+ \\
+0,000248 \cdot x_{1} \cdot x_{2}+0,000306 \cdot x_{1} \cdot x_{3}-0,00031 \cdot x_{2} \cdot x_{3} . \\
Y_{2}\left(S_{n} / S\right)=0,668755+0,044408 \cdot x_{1}-0,056635 \cdot x_{2}-0,275208 \cdot x_{3}- \\
-0,199841 \cdot x_{1}^{2}-0,200608 \cdot x_{2}^{2}-0,149047 \cdot x_{3}^{2}- \\
Y_{3}\left(\begin{array}{l}
\left.R_{a} / R_{a \text { ucx }}\right)= \\
+0,014875 \cdot x_{1} \cdot x_{2}-0,042875 \cdot x_{1} \cdot x_{3}+0,006198 \cdot x_{2} \cdot x_{3} . \\
+0,163163 \cdot x_{1}^{2}+0,048406 \cdot x_{2}^{2}+0,061634 \cdot x_{3}^{2}-
\end{array}\right. \\
-0,017354 \cdot x_{1} \cdot x_{2}+0,015312 \cdot x_{1} \cdot x_{3}+0,003099 \cdot x_{2} \cdot x_{3},
\end{gathered}
$$

where $x_{1}-$ is the total friction path, $\mathrm{mm}$;

$x_{2}$ - force per 1 microroughness of $1 \mathrm{~mm}$ of its width, $\mathrm{N}$;

$x_{3}$ - contact length, mm.

As an example, a standardized Pareto map for the surface roughness $R_{a} / R_{a}$ init is shown in Fig. 5 .

After analyzing the Pareto map for surface roughness (Fig. 5), we note the maximum influence on the optimization criterion $Y_{3}$ parameters $x_{1}$ (total friction path), $x_{3}$ (contact length) and $x_{2}$ (force per 1 microroughness of $1 \mathrm{~mm}$ of its width), which determine the change in surface roughness. Response surfaces and graphs of equal output lines for $R_{a} / R_{a}$ init are shown in Fig. 6 . Their analysis allows us to note that the lowest surface roughness is achieved with the following values of factors:

$$
x_{1} \rightarrow L \times n=18 \ldots 20 \ldots 22 \mathrm{~mm} ; x_{2} \rightarrow P_{\Sigma}=110 \ldots 130 \ldots 150 \mathrm{~N} ; x_{3} \rightarrow \Delta l=0,3 \ldots 0,35 \ldots 0,4 \mathrm{~mm} .
$$

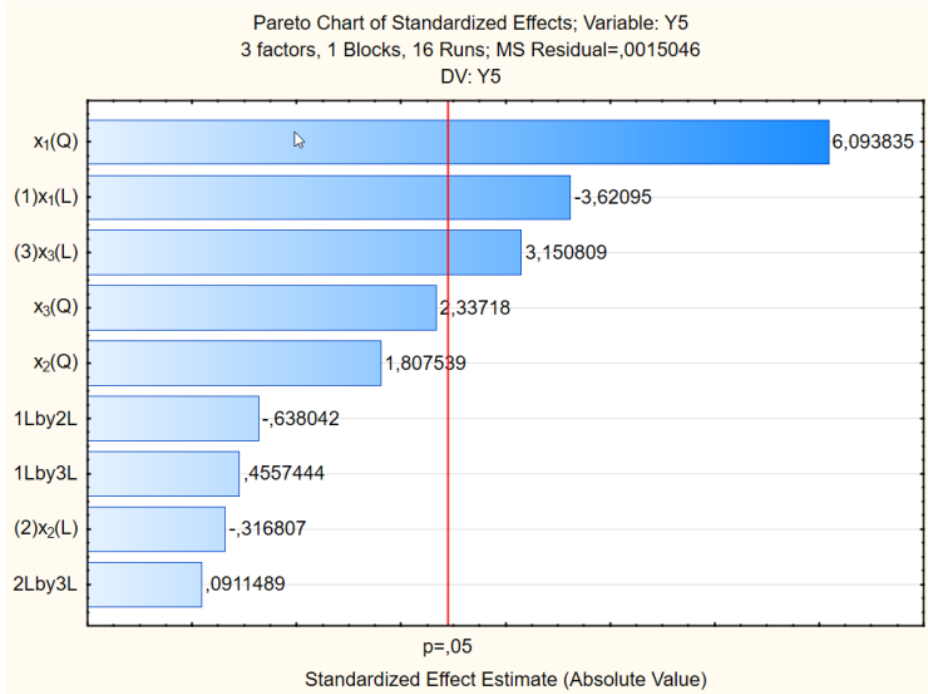

Fig. 5. Standardized Pareto map for surface roughness $\boldsymbol{R}_{a} / \boldsymbol{R}_{a}$ init 


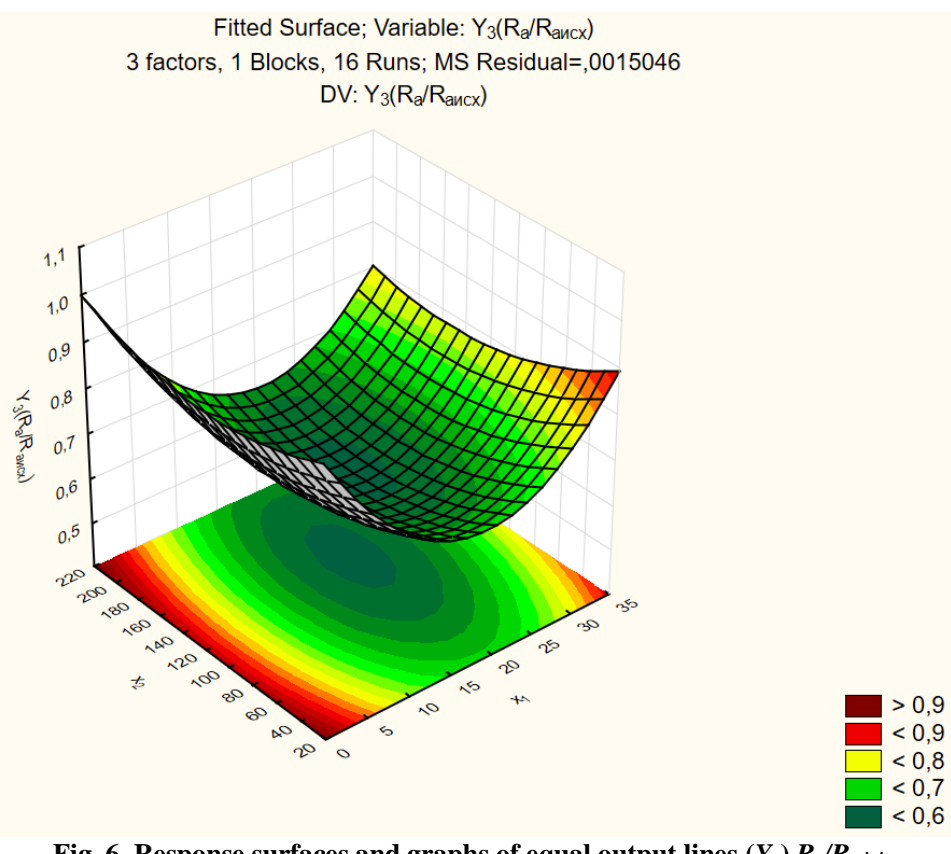

Fig. 6. Response surfaces and graphs of equal output lines $\left(Y_{3}\right) R_{a} / R_{a \text { init }}$

Similar calculations were performed for other parameters $Y_{1}(m), Y_{2}\left(S_{n} / S\right)$.

Given the inversely proportional relationship of the optimization criteria $Y_{1}(m)$ and $Y_{2}\left(S_{n} / S\right)$ with $Y_{3}\left(R_{d} / R_{a \text { init }}\right)$, achieving their maximum values is impossible at the same time, which shows the difference in the rational values of some parameters, especially parameters $x_{3}$ and $x_{1}$, therefore take the required value of this parameter based on the final result of the FANT process.

Analysis of experimental scattering graphs makes it possible to clarify the nature of factors changes and analyze their mutual influence on the three optimization criteria. Thus, when increasing the friction path $x_{1}(\Delta L)$ to $18 \ldots 20 \mathrm{~mm}$, the maximum effect of mass transfer of antifriction material is achieved. Further growth of the friction path does not increase it. This is due to the fact that the most active transfer is on the first passes of the tool. Increasing their number does not significantly affect the subsequent results of the process. In turn, the increase in the force per 1 microroughness of $1 \mathrm{~mm}$ of its width $x_{2}(P)$ to the value of $100 \ldots 140 \mathrm{~N}$ also contributes to the growth of mass transfer. However, a further increase of this technological parameter reduces the transfer of antifriction material. This nature is associated with the deformation process of the cast iron surface layer, and the increase in effort contributes to the strengthening of graphite inclusions. Cast iron becomes denser, ie there is a strengthening of cast iron. Note that the increase in mass transfer occurs at the value of the contact length $x_{3}(\Delta l)=0.3 \ldots 0.5 \mathrm{~mm}$.

Since the mass transfer of antifriction material and the area of the coating has a direct relationship, it should be noted such a pattern. At values of $x_{1}(\Delta L)=18 \ldots 20 \mathrm{~mm} ; x_{2}(P)=100 \ldots 140 \mathrm{~N} ; x_{3}(\Delta l)=0.2 \ldots 0.3 \mathrm{~mm}$, the largest coverage area is observed, which is explained by the considerations described above.

The lowest surface roughness occurs at the values of the friction path $x_{1}(\Delta L)=18 \ldots 22 \mathrm{~mm}$. Subsequent rubbing cycles do not increase the antifriction coating quality. With an increase in the force per 1 microroughness of $1 \mathrm{~mm}$ of its width $x_{2}(P)$ to values of $110 \ldots 150 \mathrm{~N}$, there is a decrease in surface roughness, due to intense mashing of antifriction material (brass L63) in the depressions of microprotrusions and smoothing of their vertices. The most rational values of the contact length $x_{3}(\Delta l)$ in terms of reducing the treated surface roughness occurs at values of $0.3 \ldots 0.4 \mathrm{~mm}$. This once again proves the influence of the surface microrelief size on the coating quality obtained with FANT.

\section{Conclusions}

Analyzing the response surfaces and graphs of equal output lines for optimization criteria and scattering graphs of technological factors, we can conclude that the rational friction path is $12 \mathrm{~mm}$, which is sufficient to achieve quality coverage from the standpoint of the considered criteria. Regarding the force per 1 microroughness of $1 \mathrm{~mm}$, it can be stated that its rational value for increasing the mass transfer of antifriction material, the coating area and reducing the surface roughness is the value at $105 \mathrm{~N}$. Regarding the value of the support surface to be treated, it should be noted that its rational value within $0.4 \mathrm{~mm}$ is clearly traced for all optimization criteria. Determined technological parameters of the FANT process will improve the quality of antifriction coatings obtained by friction-mechanical method. 


\section{References}

1. Lyashenko B.A., Solovyh E.K., Mirnenko V.I. et al. (2010). Optimization of coating technology according to the criteria of strength and wear resistance. Kiev, Ukraine: NAS of Ukraine, IPP named after Pisarenko G.S., p. 193. [in Russian].

2. Ryzhov E.V., Klimenko S.A., Gutsalenko O.G. (1994).Technological support for the quality of coated parts. Kiev, Ukraine: Naukova Dumka, p. 181. [in Russian].

3. Ragutkin A.V., Sidorov M.I., Stavrovskij M.E. (2019). Some Aspects of Antifriction Coatings Application Efficiency by Means of Finishing Nonabrasive Antifriction Treatment. Journal of Mining Institute 236, pp. 239-244. [in English].

4. Balabanov V.I., Bolgov V.Yu, Ishhenko S.A. (2010). Nanesenie treniem nanorazmerny`kh antifrikczionny`kh pokry`tij na detali. Nanotekhnologii, e`kologiya, proizvodstvo. 1(3), S. 104-107. [in Russian].

5. Shepelenko I. (2020). The study of surface roughness in the process of finishing anti-friction nonabrasive treatment. Problems of Tribology, 2020. V. 25, 1/95, pp. 34-40. [in English].

6. Pogonyshev V.A., Panov M.V. (2011). Theoretical and experimental basis for increasing the wear resistance of machine parts. Mechanics and physics of processes on the surface and in contact of solids, parts of technological and energy equipment 4, pp. 78-84. [in Russian].

7. Bersudskij A.L. (2006). The mechanism of formation of antifriction coatings during hardening treatment. VESTNIK of Samara University. Aerospace and Mechanical Engineering 2(10), pp. 81-84. [in Russian].

8. Chernovol M.I., Shepelenko I.V. (2012). Methods of forming antifriction coatings on metal friction surfaces. Collection of scientific papers of Kirovograd National Technical University "Engineering in agricultural production, industry engineering, automation”, Issue 25 (1), pp. 3-8. [in Russian].

9. Sulima A.M., Shulov V.A., Yagodkin Yu.D. (1988). Surface layer and performance of machine parts. Moscow, Russia: Mechanical Engineering, p. 240. [in Russian].

10. Prikhodko V.M., Medelyaev I.A., Fatyukhin D.S. (2015). Formation of operational properties of machine parts by ultrasonic methods: monograph. Moscow, Russia: MADI, p. 264. [in Russian].

11. Nazarov Yu.F., Shkilko A.M., Tikhonenko V.V., Kompaneyets I.V. (2007). Methods of research and control of surface roughness of metals and alloys. Physical surface engineering, Vol. 5, No. 3, pp. 207-216. [in Russian].

12. Akulovich L.M., Sergeev L.E. et al. (2018). Corrosion resistance of alloy steel parts after magnetic abrasive treatment. Bulletin of Polotsk State University. Series B, Industry. Applied Science, No. 11, pp. 45-50. [in Russian].

13. Kuzmenko I.V. (2000). Restoration and hardening of rolling bearing housings by friction rubbing with copper. PhD thesis. Moscow, p. 142. [in Russian].

14. Shepelenko I., Tsekhanov Y., Nemyrovskyi Y., Posviatenko E. (2020). Improving the Efficiency of Antifriction Coatings by Means of Finishing the Antifriction Non-abrasive Treatment. In: Tonkonogyi V. et al. (eds) Advanced Manufacturing Processes. InterPartner 2019. Lecture Notes in Mechanical Engineering, Springer, Cham, pp. 289-298. [in English].

15. Chelyubeev V.V. (1998). Razrabotka i optimizacziya rezhimov frikczionnogo latunirovaniya dlya uluchshenii prirabotki gil`z czilindrov dvigatelej v usloviyakh remontnogo proizvodstva. PhD thesis. Moscow, p. 126. [in Russian].

16. Shepelenko I.V., Cherkun V.V. (2013). Obrazovanie antifrikczionnogo pokry tiya finishnoj antifrikczionnoj bezabrazivnoj vibraczionnoj obrabotkoj. Vi`braczi yi v tekhni`czi ta tekhnologi yakh. \# 3(71). S. 99-104. [in Russian].

17. By`strov V.P., Prokopenko A.K. (1985). Finishnaya antifrikczionnaya bezabrazivnaya obrabotka v metalloplakiruyushhikh sredakh. Trenie, iznos i smazochny`e materialy`. Trudy` mezhdunarodnoj nauchnoj konferenczii. Tashkent: Izd. AN UzSSR, T.5, S. 8-9. [in Russian].

18. Pol'czer G., Firkovskij A., Lande I. (1990). Finishnaya antifrikczionnaya bezabrazivnaya obrabotka (FABO) i izbiratel`ny`j perenos. Dolgovechnost` trushhikhsya detalej mashin. Vy`p.5, Mashinostroenie, S. 86-122. [in Russian].

19. Turchkov E.V. (1982). Finishnaya antifrikczionnaya bezabrazivnaya obrabotka poverkhnostej treniya. Frikczionnoe vzaimodejstvie tverdy`kh tel s uchetom sredy`. Ivanovo, IGU, S. 135-138. [in Russian].

20. Shepelenko I., Tsekhanov Y., Nemyrovskyi Y., Posviatenko E. (2020). Power Parameters of Microcutting During Finishing Anti-friction Non-abrasive Treatment. In: Karabegović I. (eds) New Technologies, Development and Application III. NT 2020. Lecture Notes in Networks and Systems, vol 128. Springer, Cham, pp. 194-201. [in English] 
Шепеленко І.В. Вплив технологічних факторів на якість антифрикційних покриттів.

Проаналізовано умови формування антифрикційних покриттів при фінішній антифрикційній безабразивній обробці (ФАБО). Окреслено вимоги до подібного роду покриття тномера основні критерії, які застосовуються під час оцінювання їх якості. Зазначено взаємозв'язок між якістю покриття, отриманого при ФАБО, і технологічними чинниками, що визначають умови контактування інструмента 3 оброблюваною поверхнею. Доведено, що форма і розміри мікронерівностей оброблюваної поверхні визначають ефективність протікання процесу мікрорізання і заповнення мікрозападин антифрикційним матеріалом.

Дослідження впливу технологічних чинників на якість покриття при ФАБО виконувалося шляхом реалізації багатофакторного експерименту, в результаті якого встановлено вплив технологічних параметрів процесу (сумарний шлях тертя, навантаження на інструмент), а також довжини опорної поверхні на показники, що характеризують якість покриття. Отримано статистичні моделі для масоперенесення антифрикційного матеріалу, площі покриття (суцільність) і шорсткості поверхні при натуральних значеннях чинників, що дало змогу встановити вплив досліджуваних факторів на параметри оптимізації.

Аналіз експериментальних графіків розсіювання дав підстави уточнити характер змін чинників $\mathrm{i}$ проаналізувати їх взаємний вплив на критерії оптимізації. Враховуючи зворотно-пропорційний зв'язок критеріїв оптимізації, досягнення їх максимальних значень одночасно неможливе без врахування кінцевого результату процесу ФАБО. Встановлено діапазон значень досліджуваних чинників, обгрунтовано закономірності їх зміни у фокусі вибраних критеріїв оптимізації. Визначення раціональних значень технологічних параметрів процесу ФАБО дасть змогу підвищити якість антифрикційних покриттів, отриманих фрикційно-механічним способом.

Ключові слова: фінішна антифрикційна безабразивна обробка (ФАБО), антифрикційне покриття, оптимізація, суцільність покриття, масоперенесення, шорсткість. 